\title{
Campus Crime and Personal Safety in Libraries
}

\section{Otis A. Chadley}

As the rate of violent incidents increases on American college and university campuses, academic libraries are exploring ways to protect their staff and patrons. An interdisciplinary review of the literature shows that few authors have devoted attention to library security in higher education. This study surveys the literature in library science, law enforcement, the social sciences, education, and general-interest publications. General and specific crimes are discussed, and suggestions are provided on how academic libraries can improve personal safety. Suggestions include: written emergency procedures, security equipment, and crime prevention staff training, along with safer building design, staff work area rearrangement, more campus involvement in library security, and improved employee/patron communication to ensure a safe, friendly, and pro-library environment.

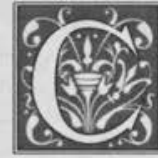

ampus crime threatens our college and university libraries, and our entire academic community. ANew York Times Magazine article called "The Campus Crime Wave" describes the personal dangers that exist on many American campuses: "From ax attacks in libraries to shootings at dances, violence on urban, suburban and rural campuses has transformed many schools into discreetly armed camps: electronic passkeys for dormitories, cold-steel mesh on classroom windows, computer-controlled cameras in stairwells, alarm strips in toilet stalls." ${ }^{11}$ Crime has become such a serious problem on campuses that in 1992, Congress passed the Crime Awareness and Campus Security Act, which requires academic institutions to report the crime rate and types of offenses occurring on their campuses. ${ }^{2}$
Criminal activity on college and university campuses is not a new phenomenon. In 1966, Charles Whitman became a mass murderer when he went on a shooting spree and killed 18 people at the University of Texas. Between 1967 and 1969, Norman John Collins murdered seven Eastern Michigan University women. In 1972-73, Edmund Kemper fatally wounded ten women at Cabrillo College and the University of California at Santa Cruz. In 1978, the infamous serial killer Ted Bundy broke into a sorority house at Florida State University at Tallahassee, and attacked and murdered two women. Bundy was alleged to have killed more than 30 people before he was captured four years later. Between 1984 and 1985, eight murders happened near the campus of Texas Christian University. ${ }^{3}$ Gun-related violence erupted at Weber

Otis A. Chadley is a Reference Librarian at the University at Albany, State University of New York; e-mail: oc286@cnsvax.albany.edu. 
State University in 1993, Simon's Rock College of Bard in 1992, and the University of Iowa in 1991. During the first three months of 1994, nine college students were shot by other students, resulting in two fatalities. ${ }^{4}$

Campus crime statistics indicate how vulnerable libraries are to violence. Daniel P. Keller, executive director of Campus Crime Prevention Programs, argues that an examination of the campus crime reports of most academic institu-

\section{In 1979, a woman was attacked by an ax-wielding assailant while studying alone in an isolated area of the stacks ... at the University of Wisconsin.}

tions would show that a substantial number of offenses occur in or around campus libraries. ${ }^{5}$ Alan J. Lizotte, executive director of the Consortium for Higher Education Campus Crime Research at the University at Albany, and Adriana Fernandez, research associate, analyzed data from the Federal Bureau of Investigation's Uniform Crime Report and report that between 1974 and 1991, violent crimes such as murder, assault, rape, and robbery steadily declined by 27 percent on academic campuses. ${ }^{6}$ However, in 1993 , safety reports provided by $774 \mathrm{col}-$ leges and universities show 1,353 robberies, an increase of approximately 12 percent from 1,210 the previous year; and 3,224 aggravated assaults, up from 3,141 the prior year. The number of rapes and forcible sexual offenses were 466 and 448 , respectively. There was a small decrease in the number of murders, from 18 to 17 ? Based on such findings, academic institutions are emphasizing the importance of providing sensible levels of security, hiring and training security and police staff, raising crime and safety consciousness, reporting dangers and criminal activity, and enforcing the laws against offenders. ${ }^{8}$

\section{Attacks on Libraries, Staff, and Patrons}

Academic libraries, library staff, and patrons are not immune to violent crime. As reported in the literature, bomb threats and bombings are perpetrated against libraries. In addition, libraries are deliberately set on fire. ${ }^{9-12}$ Although personal assaults seldom occur in libraries, ${ }^{13-15}$ such incidents are tragic when they happen. For instance, in 1979, a woman was attacked by an ax-wielding assailant while studying alone in an isolated area of the stacks, near midnight, in Madison Memorial Library at the University of Wiscon$\sin .{ }^{16}$ That same year, the library director at California Polytechnic State University in San Luis Obispo was shot and fatally wounded by the husband and son of a library employee. ${ }^{17}$ In 1983, a former library worker at the University of Florida went on a shooting rampage and shot the library director three times, fired twice at another coworker, and threatened a third staff member with deadly force. The incident left the library director paralyzed from the waist down. The disgruntled gunman was charged later with attempted first-degree murder. ${ }^{18}$ In 1990, when a library circulation assistant at Washington University in St. Louis, Missouri, attempted to stop a student from leaving the library with uncharged materials, she was attacked by the student, who cut her with fingernails, a pen, and a pencil. $^{19}$

According to Robert Willits, associate director of university personnel service at the University of Florida, perpetrators of library violence are usually "patrons or co-workers." ${ }^{20}$ Ironically, according to research conducted by Charles Bunge, these same two groups are primary sources of stress and satisfaction among library staff. ${ }^{21}$ Crime is more likely to happen in academic libraries when one of several factors exists. First and foremost, most college and university libraries have open-access policies. Anyone can enter and use their facilities and collections 
without much scrutiny. ${ }^{22-24}$ Anonymous individuals can move around in such environments and prey at will on unsuspecting victims. Second, academic libraries are open many hours, including nights and weekends. ${ }^{25,26}$ As revealed by a national survey of college and university libraries, personal safety is seriously compromised during evenings and weekends. ${ }^{27} \mathrm{~A}$ third factor contributing to crime in academic libraries is the typical separation of library facilities from the web of other campus buildings. ${ }^{28}$ Staff and patrons are more vulnerable to personal assaults when they are entering and exiting such isolated facilities. Fourth, remote or hidden areas within libraries are not monitored easily. ${ }^{29,30}$ As a result, potential rapists, exhibitionists, and robbers can hide easily and wait for their victims. Fifth, campus security and student patrols lack the personnel to monitor activity adequately in libraries. ${ }^{31}$ Between the time campus security is notified and the time it responds to a library incident, the offender may have fled the premises. The last important factor that contributes to the likelihood of crime revolves around library employees' lack of crime prevention training. ${ }^{32-34}$ As Leslie W. Sheridan warns, staff members who are not trained in crime prevention techniques may put themselves, patrons, and the library collection at risk. ${ }^{35}$

\section{Personal Library Safety}

Because no single approach to personal library safety exists, ${ }^{36}$ several security measures should be considered by academic libraries. However, libraries need to evaluate their weak areas and security requirements before implementing security measures. ${ }^{37,38} \mathrm{~A}$ security audit or checklist can help libraries define and address their vulnerability to crime. At the same time, libraries must keep in mind that fighting crime is a complex endeavor, and security programs will not eliminate crime completely. ${ }^{39}$ Nevertheless, libraries can strive to create environ- ments that expose potential victimizers. ${ }^{40,41}$ Personal safety steps that libraries need to consider include installing emergency telephones on each floor of the collection and connecting them to both a public service desk and the campus police switchboard. Whistles can be made readily available to patrons and employees who work in isolated areas. Persons entering and exiting the library should channel past a central point, such as a service desk area. Security personnel need to patrol the library regularly. Signage must be posted around the library advertising the security services available in the library. News releases can be circulated to inform the general community of the personal safety measures implemented

\section{Other suggestions included writing library emergency procedures, posting the rules of the library in noticeable areas, and training staff in crime prevention.}

by the library.42 Mary Diederich Ott and Theodore S. Markewich suggest that escort services be provided for library employees and patrons during evening hours. ${ }^{43}$ The perimeters of libraries, parking lots, and garages must be well lit for pedestrian safety. Emergency telephones should be stationed throughout campus exteriors (for example, in parking lots and garages). The landscape needs to be maintained and managed to give added physical protection. By creating surroundings that offer good visibility, pedestrian safety on campus will improve overall. ${ }^{44}$

Recently, the topic of personal library safety was discussed at a 1994 ALA preconference program entitled "Violence in the Library: Protecting Staff and Patrons," sponsored by the Buildings and Equipment Section of the Library Administration and Management Association (LAMA). During this conference, a panel of librarians and security experts shared crime prevention ideas. Some of the ideas 
suggested included equipping public service desks with duress alarms, installing scream alarms in rest rooms, and providing employees who work in remote areas with portable alarm devices. Other suggestions included writing library emergency procedures, posting the rules of the library in noticeable areas, and training staff in crime prevention. ${ }^{45}$

The literature suggests that library employees receive routine security training by public safety and law enforcement officers trained in recognizing and confronting unusual or disruptive behavior. ${ }^{46}$ Library staff members can work in groups when approaching problem patrons. ${ }^{47}$ At-

\section{Salter and ... Salter suggest that library schools increase their course offerings to include training on how to deal with behaviorally difficult patrons.}

torneys and law enforcement officials can help libraries define the types of library offenses that are prosecutable. ${ }^{48,49}$ In regard to the problem employee, library administrators may use more scrutiny before hiring applicants. The candidate's references can be contacted and the applicant screened for possible criminal activity. In addition, counseling services and programs that help former employees find new employment should be made available. ${ }^{50}$

The architectural design of academic library buildings also plays an important role in personal safety. To reduce the opportunity for criminal activity, the interiors of libraries should be designed for the greatest exposure or highest visibility in public areas, according to John Morris ${ }^{51}$ and Marvine Brand..$^{52}$ Michael Chaney and Alan F. MacDougall advise library architects to design plenty of "natural surveillance" into their interiors, particularly in susceptible areas. ${ }^{53}$ Concealed areas should be made more visible. In addition, architects need to develop and sustain a friendly and secure environment that the legitimate library user views as welcoming and efficient, while simultaneously causing worry and caution on the part of the would-be perpetrator of crime. Also, staff work areas may need rearranging for better security. Alan Jay Lincoln urges libraries to "Enhance visibility: Move a piece of furniture. Redesign a room."

Protecting library employees and patrons from crime is typically the responsibility of the college or university security division. ${ }^{55}$ In some instances, a library staff member may be assigned the duty of coordinating in-house security and serving as library liaison with campus police or security. ${ }^{56}$ Ultimately, however, it is the legal responsibility of libraries to protect their workers and clientele from foreseeable harm; otherwise, the courts could find them guilty of library negligence. ${ }^{57-59}$ Furthermore, litigation may be brought against the overall institutions for failure to act, protect, or enforce, or for other omissions of security. ${ }^{60}$ Library administrators should work with various campus groups and administrative personnel to improve security in their libraries. To develop and implement security measures, they can collaborate with campus law enforcement officers and security, the dean of students, and campus organizations. ${ }^{61}$ Charles A. Salter and Jeffrey L. Salter suggest that library schools increase their course offerings to include training on how to deal with behaviorally difficult patrons. At the same time, schools should encourage prospective librarians to take a general psychology course in order to better understand and more effectively deal with mentally disturbed patrons. ${ }^{62}$ To address the issue of personal safety, Susan Clegg, Philippa Dolphin, and Jean Sykes note "the importance of creating an atmosphere conducive to honesty and pro-library feelings." ${ }^{63}$ Jennifer Reavis believes: "If we make people feel good about themselves when they come to the library, we are establishing a positive psychological con- 
text." ${ }^{64}$ Sergeant Von L. Stambaugh of the Campus Investigations Section at the University of Toledo agrees that good interpersonal skills on the part of library workers will pay dividends in reducing library crime and improving personal safety. He comments: "A good working relationship between the library personnel and the police department is one of the major factors in keeping criminal activities down. Another is good rapport with the students." ${ }^{65}$

\section{Conclusion}

As the crime rate increases across American college and university campuses, personal library safety is becoming a real concern to academic libraries. People are being routinely victimized by individu- als in the library environment. Such offenses will continue to occur if steps are not taken to improve library security. The solutions to this dilemma are varied and complex. A multifaceted approach to library security is perhaps the most effective method of addressing the issue. Library staff must be trained by law enforcement professionals in security measures and, if necessary, work areas rearranged to improve personal safety. Library administrators and architects should work together in planning and designing security into library buildings in order to deter crime. Finally, library employees, public safety officers, and the overall academic community must work as a team to reduce campus crime and increase personal library safety.

\section{Notes}

1. Anne Matthews, "The Campus Crime Wave," New York Times Magazine (Mar. 7, 1993): 38.

2. "Social Science and the Citizen," Society 31 (Mar./Apr. 1994): 2.

3. Philip Jenkins and Edwin Donovan, "Coed Killers: Serial Murder on Campus," Campus Law Enforcement Journal 17 (July/Aug. 1987): 42.

4. Douglas Lederman, "Weapons on Campus?" Chronicle of Higher Education 40 (Mar. 9, 1994): A33.

5. Daniel P. Keller, "University of Louisville Survey Finds Library Security Problems Becoming More Complex," Campus Law Enforcement Journal 17 (July/Aug. 1987): 9.

6. "Social Science and the Citizen," 2.

7. Douglas Lederman, "Crime on the Campuses," Chronicle of Higher Education 40 (Feb. 2, 1994): A31.

8. James L. Fadenrecht, "Trends in Campus Policing," Campus Law Enforcement Journal 20 (July/Aug. 1990): 27.

9. Leonard Kniffel, "Bomb Blast Jolts Library at Michigan's Oakland University," American Libraries 21 (Mar. 1990): 180-81.

10. Donna G. Davis, "Security Problems in College and University Libraries: Student Violence," College \& Research Libraries 32 (Jan. 1971): 17.

11. Beverly Goldberg, "Arson in Asheville: Medical Library Recovering," American Libraries 21 (Mar. 1990): 182.

12. John Morris, "Protecting the Library from Fire," Library Trends 33 (summer 1984): 49-50, $55-56$.

13. Lillian N. Gerhardt, "Safe at Work?: Library Security Strategies for Staff Protection," School Library Journal 39 (Feb. 1993): 4.

14. Alan Jay Lincoln, Crime in the Library: A Study of Patterns, Impact, and Security (New York: R. R. Bowker, 1984), 79.

15. J. Kirk Brashear, James J. Maloney, and Judellen Thorton-Jaringe, "Problem Patrons: The Other Kind of Library Security," Illinois Libraries 63 (Apr. 1981): 346-47.

16. Judith A. Tuttle, "Security and Safety: UW-Madison Memorial Library Steps to Solve Problems," Wisconsin Library Bulletin 76 (May/June 1980): 135.

17. "Norman Alexander Killed on Cal. Poly. Campus," American Libraries 10 (Mar. 1979): 100.

18. "U of Fla. Library Director Shot by Former Employee," American Libraries 14 (June 1983): 334.

19. "University Fires Library Assistant Who Claims Student Assault," American Libraries 22 (Sept. 1991): 698.

20. Wilda W. Williams, "A Prescription for Prevention," Library Journal 119 (Aug. 1994): 38.

21. Charles Bunge, "Stress in the Library," Library Journal 112 (Sept. 15, 1987): 48. 
22. Rachel MacLachlan, "Factoring Loss into the Budget," Library Journal 119 (Aug. 1994): 36.

23. Keller, "University of Louisville Survey," 9-10.

24. Richard M. Dougherty, "Security in Libraries: User Groups and Physical Access," Library Issues: Briefings for Faculty and Administrators 6 (July 1986): [1-2].

25. Susan Clegg, Philippa Dolphin, and Jean Sykes, "Security in Academic Libraries," Library Association Record 91 (Feb. 1989): 94.

26. Keller, "University of Louisville Survey," 9-10.

27. Ibid., 10.

28. Marvine Brand, ed., Security for Libraries: People, Buildings, Collections (Chicago: ALA, 1984), 46.

29. Michael Chaney and Alan F. MacDougall, eds., Security and Crime Prevention in Libraries (CITY, Vt.: Ashgate Publishing Company, 1992), 50-51.

30. Dougherty, "Security in Libraries," 1-2.

31. Association of Research Libraries, Building Security and Personal Safety Kit 150 (Washington, D.C.: ARL Office of Management Services, 1989), [i].

32. Alan Jay Lincoln and Carol Zall Lincoln, "Library Crime and Security," Library \& Archival Security 8 (spring/summer 1986): 13-14.

33. Brashear, Maloney, and Thorton-Jaringe, "Problem Patrons," 346-47.

34. Mary J. Cronin, "A Workshop Approach to Library Security," Library \& Archival Security 3 (spring 1980): 50.

35. Leslie W. Sheridan, "People in Libraries As Security Agents," Library \& Archival Security 3 (spring 1980): 61.

36. Robert Chadbourne, "Disorderly Conduct: Crime and Disruptive Behavior in the Library," Wilson Library Bulletin 68 (Mar. 1994): 25.

37. Susan Hildreth, "What Libraries Are Doing," Library Journal 119 (Aug. 1994): 39.

38. Williams, "A Prescription for Prevention," 38.

39. Alan Jay Lincoln and Carol Zall Lincoln, "Controlling Crime: A Security Checklist," Library \& Archival Security 8 (spring/summer 1986): 146.

40. Williams, "A Prescription for Prevention," 38.

41. Chaney and MacDougall, Security and Crime Prevention in Libraries, 50-51.

42. Tuttle, "Security and Safety," 135-36.

43. Mary Diederich Ott and Theodore S. Markewich, Report of the Security Survey at the University of Maryland at College Park: Executive Summary (College Park: Univ. of Maryland, Office of Institutional Studies, 1983), 1-52.

44. Brand, "Security for Libraries," 40.

45. Williams, "A Prescription for Prevention," 38.

46. John R. Kleberg, "An Rx for Library Security," Library \& Archival Security 4 (1982): 27.

47. Williams, "A Prescription for Prevention," 38.

48. Ibid.

49. Lincoln, "Crime in the Library," 146.

50. Williams, "A Prescription for Prevention," 38.

51. John Morris, The Library Disaster Preparedness Handbook (Chicago: ALA, 1986), 75.

52. Marvine Brand, "Security of Academic Library Buildings," Library \& Archival Security 3 (spring 1980): $41-42$.

53. Chaney and MacDougall, Security and Crime Prevention in Libraries, 51.

54. Chadbourne, "Disorderly Conduct," 24.

55. Brand, Security for Libraries, 24.

56. Crime Prevention, Security and Emergency Procedures for College and University Libraries (Goshen, Ky:: Campus Crime Prevention Programs, 1986), 1.

57. Johnathan S. Tryon, "Premises Liability for Librarians," Library \& Archival Security 10 (1990): 5-6.

58. Silva E. Barsumyan, "Premises Liability," New Jersey Libraries 21 (spring 1988): 9-12. 98.

59. Carol B. Allred, "Negligence Law for Libraries," Law Library Journal 77 (1984/1985): 195-

60. Fadenrecht, "Trends in Campus Policing," 27.

61. Tuttle, "Security and Safety," 135.

62. Charles A. Salter and Jeffrey L. Salter, On the Frontlines: Coping with the Library's Problem Patrons (Englewood, Colo.: Libraries Unlimited, 1988), 141.

63. Clegg, Dolphin, and Sykes, "Security in Academic Libraries," 94.

64. Jennifer Reavis, "Patron Relations: A Transformational Approach," Texas Libraries 50 (winter 1989/1990): 133.

65. Von L. Stambaugh, "University of Toledo: Fighting Crime through Prevention and Enforcement," Campus Law Enforcement Journal 17 (July/Aug. 1987): 16. 


\section{The \\ State \\ of the Art}

Information

industry

leaders in

providing subscription services, article delivery \& library automation software.

REMO $^{8}$ Mouse driven serials management system.

Ross $^{\otimes}$ Online ordering, claiming and searching of journal and publisher databases.

RENEWAL EXPRESS PC-based system to analyze current serials holdings and plan for future collection development.

FinANCLAL PlanNer Lotus formatted worksheet to analyze previous spending history and plan future budget allocations.

\section{BACKSERV/BACKMED}

An Internet list solely devoted to the informal exchange of serial back issues among libraries.

\section{WORLD WIDE WEB}

http://www.readmore.com

\section{Readmore Academic Services}

700 Black Horse Pike, Suite 207

Phone: 1-800-645-6595

Blackwood, NJ 08012

Fax: 609-227-8322 